SCHOOLS OF THOUGHT 



\section{Schools of Thought}

TWENTY-FIVE YEARS OF INTERPRETIVE

SOCIAL SCIENCE

EDITED BY

Joan W. Scott

Debra Keates

PRINCETON UNIVERSITY PRESS

PRINCETON AND OXFORD 
Copyright (C) 2001 by Princeton University Press

Published by Princeton University Press, 41 William Street,

Princeton, New Jersey 08540

In the United Kingdom: Princeton University Press, 3 Market Place,

Woodstock, Oxfordshire OX20 ISY

\section{All Rights Reserved.}

\section{Library of Congress Cataloging-in-Publication Data}

Schools of thought : twenty-five years of interpretive social science / edited by Joan W. Scott, Debra Keates.

p. cm.

Papers presented at a conference.

Includes bibliographical references.

ISBN 0-691-08841-1 (alk. paper)

ISBN 0-691-08842-X (pbk. : alk. paper)

1. Social sciences - Congresses. I. Scott, Joan Wallach. II. Keates, Debra.

H22.S36 2001

$300-\mathrm{dc} 21 \quad 2001019856$

\section{PUBLICATION ACKNOWLEDGMENTS}

Peter Galison's essay, "Material Culture, Theoretical Culture, and Delocalization," was published in Science in the Twentieth Century, ed. John Krige and Dominique Pestre (OPA [Overseas Publishers Association] N.V., 1997). It is reprinted here with permission from Gordon \& Breach Publishers.

Joan Scott's essay, "After History," appeared in Common Knowledge 5:3 (winter 1996).

Anna Tsing's essay, "The Global Situation," appeared in Cultural Anthropology 15:3 (August 2000): $327-60$. It is reprinted here with permission from the American Anthropological Association.

Michael Walzer's essay, "International Society: What Is the Best that We Can Do?" was given as the Multatuli Lecture at the Catholic University of Leuven and published in the journal of the European Ethics Network, Ethical Perspectives, December 1999. A different version appeared in Dissent, fall 2000.

This book has been composed in Times Roman

Printed on acid-free paper. $\infty$

www.pup.princeton.edu

Printed in the United States of America

$\begin{array}{llllllllll}10 & 9 & 8 & 7 & 6 & 5 & 4 & 3 & 2 & 1\end{array}$

$\begin{array}{llllllllll}10 & 9 & 8 & 7 & 6 & 5 & 4 & 3 & 2 & 1\end{array}$

(pbk). 